\title{
Erythema ab igne in an individual with diabetes and gastroparesis
}

\author{
Ravikumar Ravindran ${ }^{1,2}$
}

'Diabetes and Endocrinology, Cardiff University

${ }^{2}$ University Hospital Wales

\section{Correspondence to} Dr Ravikumar Ravindran dr.ravimrcp@gmail.com, dr.ravimrcp@gmail.com

Accepted 22 September 2017

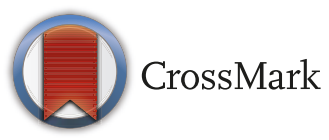

To cite: Ravindran R. BMJ Case Rep Published Online First: [please include Day Month Year]. doi:10.1136/ bcr-2014-203856

\section{DESCRIPTION}

Prolonged abdominal heat application in an individual with diabetes and gastroparesis leads to the development of erythema $a b$ igne. Practitioners should be aware of the various ways that erythema ab igne can present. ${ }^{1}$

Erythema ab igne is due to prolonged heat exposure $\left(43-47^{\circ} \mathrm{C}\right)$ which causes damage to superficial vascular plexus leading to vasodilation, erythema and haemosiderin deposition which clinically appears as hyperpigmentation. ${ }^{2}$

A 28-year-old man with type 1 diabetes and gastroparesis had presented with vomiting and abdominal pain. Abdominal examination revealed a erythematous, reticulated, macular and non blanchable pigmentation, (figure 1). The patient used to apply hot water bottles for abdominal pain relief.

Erythema ab igne can be associated with epidermal atrophy and scaling. ${ }^{1}$ The lesions may become keratotic and bullous (rare) with a slightly burning sensation. ${ }^{23}$

Important differentials include other reticulated conditions such as livedo reticularis and livedoid vasculitis, cutis marmorata, poikiloderma atrophicans vasculare and cutaneous T-cell lymphoma.

Management is mainly removing the heat source. 5-fluorouracil is recommended if the lesion shows precancerous changes and can help clear epithelial atypia. Topical tretinoin or laser is advocated for improving skin pigmentation. ${ }^{45}$

Biopsy of the lesion was not performed in the patient as it was clear that the lesion was due to application of heat source as the lesion

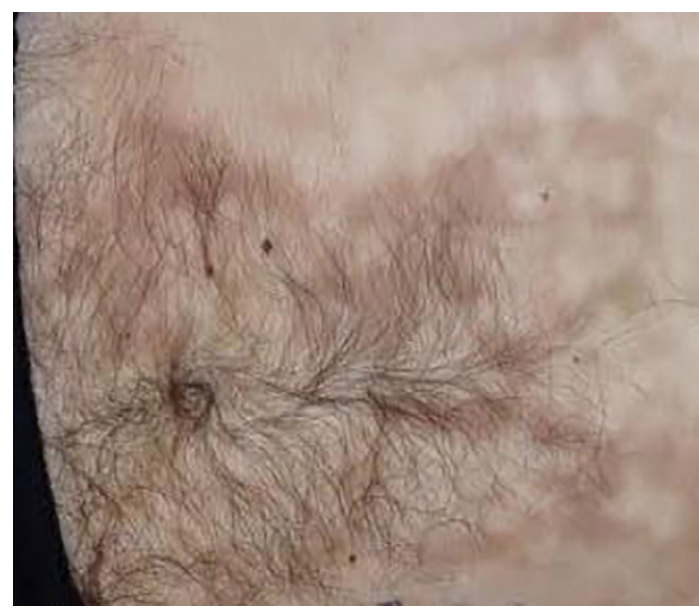

Figure 1 Erythema ab igne in an individual with diabetes and gastroparesis.
Learning points

- Erythema ab igne indicates the severity of the underlying cause for example, pain thereby leading to prolonged heat application.

- Practitioners need to be aware of the different ways of presentation of erythema ab igne.

started to fade during the patient's hospital stay. ${ }^{6}$ Biopsy is usually recommended to rule out cancer if lesions are not fading after the removal of heat source. ${ }^{7}$

Contributors RR is the sole author of this manuscript.

Competing interests None declared.

Patient consent Obtained.

Provenance and peer review Not commissioned; externally peer reviewed.

Author note A young patient hadpresented with abdominal pain and vomiting in the evening. He was a type 1 diabetic with gastroparesis. On admission, high glucose levels were noted and he was treated overnight with variable rate insulin infusion to control his glucose levels as he was unable to eat due to his vomiting and abdominal pain. When he was seen by the on-call medical consultant, he was found to be lying in bed in a curled up position and with his hand on his abdomen. Examination of his abdomen revealed erythema ab igne lesion and the patient informed that hehad been using hot water bottles/bags to relieve himself of his pain. An erythema ab igne lesions are usually found in elderly. Patients who often sitnear the fire during winter time to keep themselves warn, this lesion presenting in a young man with diabetic gastroparesis was striking which indicated the severity of the pain secondary to gatroparesis. A quick literature search did not reveal any gastroparetic patient presenting with this type of lesion, although an astute physician can make a diagnosis of hypothyroidism when such lesion presents in the shin area of hypothyroid patients due to theirproximity to heating devices to keep themselves warm. It was felt that this would be a good pictorial case presentation for general physicians so that they can be aware of the different ways of presentation of erythema ab igne. Also the lesion can also be precancerous and is one of the differentials.

(c) BMJ Publishing Group Ltd (unless otherwise stated in the text of the article) 2017. All rights reserved. No commercial use is permitted unless otherwise expressly granted.

\section{REFERENCES}

1 Helm TN, Spigel GT, Helm KF, et al. Erythema ab igne caused by a car heater. Cutis 1997;59:81-2.

2 Bolognia JL, Jorizzo JL, Schaffer JV. Dermatology. 3rd edn. China: Elsevier Saunders, 2012.

3 Goldsmith LA, Katz SI, Gilchrest BA, et al. Fitzpatrick's dermatology In general medicine. 8th edn. USA: Mcgraw Hill, 2012.

4 Champion RH, Burton JL, Burns DA, eds. Rook/Wilkinson/ Ebling Textbook of Dermatology. 6th edn. UK: Blackwell Science, 1998.

5 Salgado F, Handler MZ, Schwartz RA, et al. Erythema ab igne: new technology rebounding upon its users? Int I Dermatol 2017. [Epub ahead of print: 30 Mar 2017]. 


\section{Images in...}

6 South AM, Crispin MK, Marqueling AL, et al. A hyperpigmented reticular rash in a patient on peritoneal dialysis. Perit Dial Int 2016;36:699-700.
7 Erythema ab igne | DermNet New Zealand. Dermnetnz.org 2017. cited 6 Aug 2017 https://www.dermnetnz.org/topics/erythema-ab-igne/

Copyright 2017 BMJ Publishing Group. All rights reserved. For permission to reuse any of this content visit

http://group.bmj.com/group/rights-licensing/permissions.

BMJ Case Report Fellows may re-use this article for personal use and teaching without any further permission.

Become a Fellow of BMJ Case Reports today and you can:

- Submit as many cases as you like

- Enjoy fast sympathetic peer review and rapid publication of accepted articles

Access all the published articles

- Re-use any of the published material for personal use and teaching without further permission

For information on Institutional Fellowships contact consortiasales@bmjgroup.com

Visit casereports.bmj.com for more articles like this and to become a Fellow 